\title{
IS MEDIA-MULTITASKING ECHT ZO SLECHT VOOR
}

JONGEREN?

In deze rubriek laat de redactie van Kind \& Adolescent Praktijk een promovendus aan het woord om te vertellen over zijn of haar onderzoek.

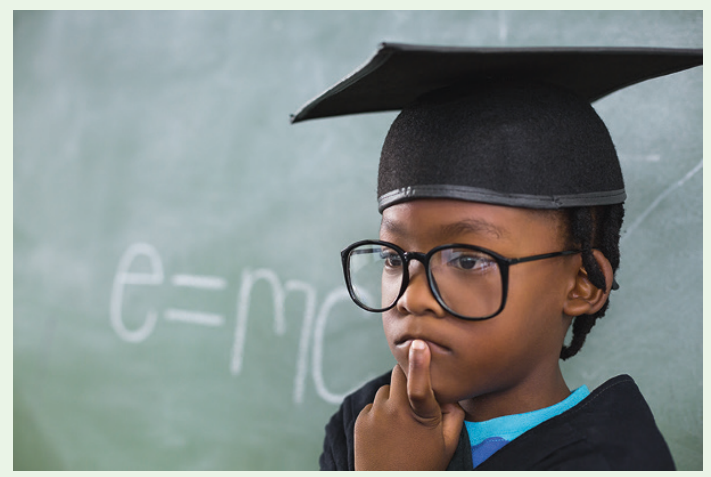

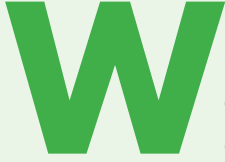
inneke van der Schuur promoveerde op 22 februari 2018 aan de Universiteit van Amsterdam op haar proefschrift Juggling with Media. The Consequences of Media Multitasking for Adolescent Development.

\section{Waarom dit onderzoek?}

Mijn onderzoek is ontstaan vanwege de zorgen in de maatschappii over overmatig gebruik van de media door jongeren en de prikkels die jongeren voortdurend binnenkrijgen. Wat doet dit met hun aandacht en concentratie, slaap en schoolprestaties op de langere termijn? Eerdere studies laten een negatieve relatie zien tussen media-multitasking en ontwikkelingsdomeinen, zoals cognitieve controle en sociaal-emotioneel functioneren, maar dit waren voornamelijk studies onder jongvolwassenen en ze waren niet longitudinaal.

Ik heb 1400 jongeren van elf tot vijftien jaar op drie momenten in één schooljaar getest en gekeken of media-multitasking invloed heeft op hun schoolprestaties en aandacht op school, emotioneel functioneren en slaap. Wat uit mijn onderzoek blijkt, is dat jongeren die gedurende de dag veel switchen tussen mediaactiviteiten meer aandachtsproblemen op school rapporteren en moeilijkheden ervaren met hun slaap.

\section{Wat hebben kinderen en opvoeders} hieraan?

Langetermijnresultaten vit mijn onderzoek laten zien dat het belangrijk is om voorzichtig te zijn met het switchen tussen media. Jongeren zouden zich meer bewust moeten worden van hun eigen mediagebruik, maar ook hun opvoeders. Jongeren zouden kunnen gaan ervaren: 'Wat doet het mediagebruik met mije' Ook hun ouders kunnen zich dat afvragen. Mediawijsheidprogramma's kunnen helpen bij de bewustwording, maar ook met apps kan tegenwoordig het eigen mediagebruik gevolgd worden. Het is belangrijk dat de ouders zelf als rolmodellen niet te veel gaan switchen in gesprekken met hun kind. $\mathrm{Bij}$ bepaalde gezinsactiviteiten, zoals samen een tv-programma bekijken of samen eten, zou het handig zijn als de mobiele telefoons ergens anders liggen. Gebruik van media wordt steeds noodzakelijker bij het huiswerk, maar ook dan zou mediagebruik ingeperkt kunnen worden door bijvoorbeeld een tijdslimiet in te stellen, eventueel afgewisseld met een korte media-activiteit.

\section{Wat hebben professionals en beleid-} smakers eraan?

Het zou handig zijn om op scholen consistente regels te hebben over mediagebruik, het liefst op het schoolniveau. Er moet ook steeds worden gekeken of het inzetten van media het onderwijs ondersteunt of juist verstoort. Als jongeren bijvoorbeeld naar muziek mogen luisteren tijdens de lessen, is dat dan muziek voor een betere concentratie of gaat het om een willekeurige clip op YouTube? Verder wordt er voornamelijk gepraat over mediagebruik tijdens de lessen, maar scholen kunnen bijvoorbeeld ook een mediavrije pauze instellen, eens per week.

Als een jongere slaapproblemen vermeldt, zou ik altijd mediagebruik vitvragen. Hetzelfde geldt voor aandachtsproblemen. Ook dan is het goed om te kijken naar mediagebruik en de hoeveelheid prikkels die de jongere dagelijks binnenkrijgt. Even niets doen en zich afzonderen van de prikkels kan dan heel belangrijk zijn.

Daarnaast zien we in verschillende onderzoeken veel individuele verschillen in de effecten van mediamultitasking op iemands functioneren. Het kan zijn dat sommige jongeren minder last hebben van mediamultitasking en alle prikkels die ze moeten verwerken. Op basis van deze individuele patronen zou een advies geformuleerd kunnen worden voor een specifieke adolescent. 